\title{
FACINE: Re-Configuring the Filipino in Film in the West, Its Challenges and Possibilities
}

Mauro Feria Tumbocon, Jr.

Dilemmas plague any attempt at showcasing Filipino films outside the Philippines and especially in the United States where Filipino Americans form the largest group of overseas Filipinos. Implicit in such an undertaking is representing what organizes a national cinema on the world stage while remaining mindful of past assumptions about what constitutes Filipino cinema.

The issue of representation becomes imperative when organized within a Filipino-specific project, as opposed to projects initiated by a nonFilipino cultural institution with its own parameters for inclusion. This is where a nonprofit Filipino American organization like the Filipino Arts \& Cinema International (FACINE) fits in. Envisioned as a community-based organization, FACINE proposes to institutionalize the public exhibition of Filipino films in the United States through an annual film festival that draws support primarily from the community.

FACINE descends from SINE! SINE! The first Filipino American Film \& Video Festival, which was established as part of the Filipino American Arts Exposition in August 1994, a month-long celebration of Filipino arts and culture featuring representative pieces from theater, visual arts, film, and literature. The outdoor fair was held at the Yerba Buena Center for the Arts.

As program director of the Exposition's film component, I sought to survey film and video works produced and/or directed by Filipino-American media artists. Without periodizing the survey, I received all available entries to establish a reference for Filipino American cinema.

Iorganizedfifteen short videos according to themes or subjects, including: Filipino-American history, Philippine contemporary sociopolitical realities, and gender and sexuality.

A parallel program of nine Philippine-produced films was held at the Asian Art Museum, a major cultural institution; the program included classics like Ishmael Bernal's Himala [Miracle] (1982), Eddie Romero's Ganito Kami Noon, Paano Kayo Ngayon? [This Is How We Were, How Are You Now?] (1976), and Lino Brocka's Orapronobis [pray for us] (1989) all screened in $35 \mathrm{~mm}$ with the intent to introduce Philippine cinema to a wider audience.

My task as programmer was to explore the contentious issue of the Filipino American identity in film, and Filipino representation for foreign audiences, including Filipino Americans. 
As a newly arrived immigrant, the challenge lies in recognizing that Filipino American filmmaking was not regular cultural practice in the mid1990s. Filipino American films were limited to a few short films whose screenings were confined to universities and metropolitan centers: Los Angeles, New York, and San Francisco.

What is Filipino cinema, much more Filipino American? This, I wrote in what was initially billed as the Filipino American Film \& Video Festival:

Is being Filipino contingent on the artist's geographic origins? Should we define a film in terms of being Filipino, as subject or object of the particular work? Does it matter? If it does, when is it important? How do filmmakers appropriate that which is natural to their ethnic roots in the creation of their works?

Being Filipino is no longer a matter of geography. It is a sense of belonging to one's own culture and to a larger reality. "Filipino" is informed by inclusion in an everchanging community, and new identities emerging from the past and continuing to the present. Filipinoness is not only where we were born, but also what we are becoming in diaspora, colonial history, and intersections with other cultures and nations. We live at a time and place where we are both singular and plural, ethnic and multi-cultural.

For three years and until the festival's departure from FAAE in 1996 due to lack of funding and internal disagreement, two curatorial elements emerged:

1. Initiate and continue the conversation about the identity of Filipino American cinema, and the Filipino in Filipino American films;

2. Explore the role of diasporic experience: as subject, style, or what could be a more inclusive Filipino cinema

It is important to take note of the paucity of materials when defining Filipino American cinema, given that Filipino American films are few and far between. Production is limited to short films and its sustainability hampered by lack of institutional support that could provide more regular exposure, owing probably to an assumption that an audience was just not there, rather still untapped.

FACINE worked to institutionalize the public exhibition of Filipino and Filipino American films, and to build an audience for these films. 
Until the world premiere of Francisco Aliwalas's Disoriented (1999) at the National Asian American Telecommunications Association (NAATA)'s with the Asian American International Film Festival (now called the Center for Asian American Media (CAAM)) in March 1999 in San Francisco. During the post-screening Q\&A, I declared the occasion "historic, since we have just witnessed the screening of the first-ever Filipino American feature-length film." It was difficult to begin defining the Filipino in Filipino American film.

Aliwalas's Disoriented [Pinatubo Films, 1999] is a story familiar to immigrant communities: a heartwarming comedy featuring a twentysomething Filipino-American dealing with an "overbearing mother who wants him to be a doctor, and the return of a long-lost brother who trades high tops for high heels" (Lam, n.d.)

At the core of Aliwalas's film and, later, the work of many other Filipino-American filmmakers-notably Gene Cajayon's The Debut [5 Card Productions, 2000] and Rod Pulido's The Flip Side [Pure Pinoy, 2001]-is the displaced Filipino family's process of adapting in the United States and creating a distinctly Filipino identity in a multi-cultural society like America. Pulido's The Flip Side was the first film by a Filipino filmmaker accepted to and screened at the Sundance Film Festival.

While short films remain more common, feature-length film as form, be it fiction or non-fiction, affords more valuation because of wider access through theatrical screening and video distribution across varied platforms, and audience reach for programming purposes.

Since Aliwalas's breakthrough film in 1999-his first and last on the subject before he began a career in documentary film production for cable channels-there have been little more than thirty feature-length films produced by Filipino American media artists. Most artists made only one film, a fact that invites questions:

- Why can't Filipino American filmmakers sustain creative work?

- What is the impact of an ill-defined market, and lack of a support network-producers, financiers, production staff-in the face of an established industry like Hollywood and its attendant prejudicial treatment of minority artists?

A cursory look at the Filipino American films produced and screened reveals three filmic trends:

1. Films that directly dramatize and present the Filipino American experience and/or Philippine realities from a Filipino American 
perspective, exemplified the dramatic comedies of Aliwalas, Pulido, and Cajayon, the musical films of H.P. Mendoza (Colma: The Musical, 2006; Fruit Fly, 2009), the documentary works of Angel Velasco Shaw (Nailed, 1991; Asian Boys, 1999; The Momentary Enemy, 2008), and Ramona Diaz (Imelda, 2003; The Learning, 2011; Don't Stop Believing: Every Man's Journey, 2012; Motherland, 2017);

2. Films belonging to experimental genre forms like science fiction, adventure-thriller, and horror with their characteristic B-movie aesthetics, notably Alvin Ecarma's brilliant send-up of Hong Kong Kung Fu film in Lethal Force (2001), Ron Santiano's female characterdriven action adventure films (Eve, 2008; The Chronicles of the Order, 2010; Prophecy of Eve, 2014) and, lately, Matthew Abaya's brilliant horror movie, Vampariah (2016). These films are genre-based using Filipino-American actors and drawing on Filipino myth;

3. Films by Filipino filmmakers where being Filipino is totally absent as subject-matter: David Maquiling (Too Much Sleep, 2011) and Q Allan Brocka's queer films (Eating Out, 2004; Boy Culture, 2006)

To the extent that Filipino Americans constitute an immigrant community, Filipino American films must be seen as diasporic; Filipino nationhood, even as concept, is vital in the formation of identity and selfhood in America.

In the ensuing years of the festival, this realization has led FACINE to address concerns of two distinct, yet overlapping audiences: FilipinoAmericans born in the US, and those recently-immigrated. These audiences are concerned with representation in film that would contribute to a strong sense of identity in a multicultural America.

No longer was entering the mainstream the sole reason for the festival's existence-FAAE emphasized the need to address the lack of media representation in American society to provide a forum, an avenue for the community to come together and celebrate its art and culture, its own cinema.

During a forum, I was asked why an ethnically-specific Filipino film festival was necessary-a question presumably asked in the context of an already popular Asian American film festival in San Francisco. I quickly responded, why not? I just would like to see my face on the screen!

My response may be seen as statement of ethnic pride-consider that the Philippines at one time was one of the five biggest film producers in the world. Filipinos have an enviable cinematic tradition. A festival creates a platform for self-representation for a community of immigrants that 
continues to be invisible and silenced. This process of identity narrativizing is particularly important for Filipinos born in the US and modifying their personal self-narratives. The potency of a film like Aliwalas's Disoriented presented on the big screen in 1999, where its characters even assume multiple identities along race, ethnicity, class and gender, should therefore not be underestimated.

Films by Filipino American filmmakers are part of diasporic or exilic cinema, which altogether raise the issues relevant to immigrant communities: cultural alienation/dislocation, invisibility or marginalization, and postcolonial/post-racial subjectivities.

This warrants a more thorough examination of films produced and/or directed by Filipino American media artists, but this will suffice for now.

Contingent on need for identity formation in film and other creative arts, among artists in diaspora, is a growing concern for perception by the dominant culture.

In the wake of the Best Director triumph of Brillante Mendoza at the Cannes Film Festival in 2009 for his film Kinatay [Butchered/The Execution of $\mathrm{P}]$, the subsequent media coverage in the US and its limited theatrical screening-years after the popularity of the "macho dancer" movies in America following Lino Brocka's Macho Dancer (male gigolo-dancers) (1988), which included Mel Chionglo's Sibak: Midnight Dancers (sibak = hard fuck) (1994) and Burlesk King (1999), both set in Manila's slumsraised renewed concerns in the Filipino community about the depiction of Philippine poverty in film, especially by acclaimed foreign critics.

Pop culture representation of the nation, its people, and the pervasive portrayal of twenty-first century life in the slums suggests that thiscinema is a reflection of how the West represents the nation.

In this light, FACINE intervenes by representing the nation and our people on our own terms. The dominant image of the Philippines in Western films depicts the Filipino as living in abject poverty, amid crime and extreme desperation. This outdated image requires a new national myth, a shift in representation of the nation, and opportunities for narratives of redemption from abjection.

Despite the critical acclaim given Filipino slum movies in Europe, no film of such nature, with the exception of Brocka's Macho Dancer, has achieved commercial success in the US. No Filipino slum movies have been distributed in the US; FACINE sees this an opportune time to re-configure the Filipino in film, in America.

While the festival has slowly gained ground in the community, and earned mainstream respect at the same time, FACINE believes in the need 
to initiate and organize a strong educational program to support Filipino film, build on its audience, and enable Filipino cinema to become a vital platform for more critical engagement among Filipinos and with the greater community. 


\section{References}

Lam, K. (n.d.). Disoriented (1999). Retrieved from http://www.imdb.com/title/tt0272583/ plotsummary?ref_=tt_ov_pl

MAURO FERIA TUMBOCON JR cultural worker and writer/journalist, has written extensively on Filipino cinema and popular culture for more than two decades, both in the United States and in the Philippines. A former member of the Manunuri ng Pelikulang Pilipino,1986-1989, he co-founded the interdisciplinary critics groups, the Young Critics Circle, 1990 and Kritika, 1992 in Manila and is currently, a member of the Asian Writers Institute, a California-based organization of writers and journalists.

Mr. Tumbocon organized the first Filipino American film festival in San Francisco in 1993, the largest ever shown in the United States. He is founder and current director of FACINE or Filipino Arts \& Cinema, International (formerly known as Filipino American cineArts), a nonprofit media arts group that aims to promote and develop transnational Filipino cinemas. FACINE has continuously held the annual filipino international cine festival for the past 25 years. (corresponding author: mtumbocon@gmail.com). 
